\title{
Enhanced degradation of 2,4-dinitrotoluene by ozonation in the presence of manganese(II) and oxalic acid
}

\author{
Hua Xiao ${ }^{\mathrm{a}, \mathrm{b}}$, Ruiping Liu ${ }^{\mathrm{a}}$, Xu Zhao ${ }^{\mathrm{a}}$, Jiuhui $\mathrm{Qu}^{\mathrm{a}, *}$ \\ a State Key Laboratory of Environmental Aquatic Chemistry, Research Center for Eco-Environmental Sciences, \\ Chinese Academy of Sciences, Beijing 100085, China \\ b Graduate School of Chinese Academy of Sciences, Beijing 100039, China
}

\section{A R T I C L E I N F O}

\section{Article history:}

Received 1 January 2008

Received in revised form 19 February 2008

Accepted 19 February 2008

Available online 23 February 2008

\section{Keywords:}

Catalytic ozonation

Hydroxyl radical

DNT

Manganese ion

ESR

\begin{abstract}
A B S T R A C T
Manganese catalytic ozonation of 2,4-dinitrotoluene (DNT) in the presence of oxalic acid was studied. The addition of manganese ion $\left(\mathrm{Mn}^{2+}\right)$ or oxalic acid alone in ozonation process did not enhance DNT degradation, but the addition of $\mathrm{Mn}^{2+}$ coupled with oxalic acid accelerated degradation of DNT. The DNT degradation efficiency was influenced by carbonate in the catalytic ozonation process. Kinetics study showed that $\mathrm{Mn}^{2+}$ catalytic ozonation significantly promoted the decomposition of ozone. Experimental results of electron spin resonance (ESR) demonstrated that addition of $\mathrm{Mn}^{2+}$ and oxalic acid produced much hydroxyl radicals in catalytic ozonation system than that in single ozonation system. These results suggested that catalytic ozonation followed hydroxyl radical-type mechanism. $\mathrm{Mn}^{2+}$ promoted decomposition of ozone to produce hydroxyl radical and it was oxidized into manganese oxide. Manganese oxide was reduced into $\mathrm{Mn}^{2+}$ by oxalic acid, which is the key step of catalytic process. Based on above results, a cycle catalytic mechanism of $\mathrm{Mn}^{2+}$ was proposed. Intermediates were determined by HPLC and GC-MS, and they mainly included aromatic organics and aliphatic carboxylic acids.
\end{abstract}

(c) 2008 Elsevier B.V. All rights reserved.

\section{Introduction}

In recent two decades, there has been an extensive research interest in catalytic ozonation that combine a transition metal with ozone for enhanced oxidation of refractory organic species [1]. In terms of different kinds of catalysts adopted, catalytic ozonation can be divided into homogeneous and heterogeneous catalytic ozonation. Homogeneous catalysts mainly include several transition metal ions, such as $\mathrm{Co}^{2+}$ and $\mathrm{Mn}^{2+}[2,3]$. Heterogeneous catalytic ozonation is activated by metal oxides or metal oxides on supports $[1,4]$. Catalytic ozonation corresponding to different catalysts includes two following catalytic mechanism [1]: firstly, the catalyst promotes ozone decomposition to generate highly reactive hydroxyl radical; secondly, the catalyst adsorbs ozone or organics to form highly oxidative species or intermediates which are prone to be oxidized by ozone.

Manganese salts or manganese oxides have been used as catalysts for ozonation in numerous studies. Manganese-catalyzed ozonation of pyruvic acid in aqueous solution were observed by Andreozzi et al. [5]. And, they considered that Mn(IV)-catalyzed ozonation of pyruvic acid and simultaneously Mn(IV) became

\footnotetext{
* Corresponding author. Tel.: +86 10 62849151; fax: +861062923558

E-mail address: jhqu@rcees.ac.cn (J. Qu).
}

$\mathrm{Mn}(\mathrm{VII})$, which oxidized pyruvic acid into acetic acid. Ma et al. [6] supported manganese oxides $\left(\mathrm{MnO}_{x}\right)$ on granular active carbon (GAC) to enhance the oxidation of nitrobenzene by ozone. They suggested that in $\mathrm{MnO}_{x} / \mathrm{GAC}$-catalyzed ozonation, the adsorption of organic micro-pollutants on catalyst was an important step, which would have a direct influence on the catalytic effectiveness of the heterogeneous catalytic system. Ma and Graham [7] also reported that in the presence of a small amount of Mn(II) the oxidation of atrazine by ozone was greatly enhanced. They suggested a possible radical mechanism and catalytic ozonation of atrazine might be caused by the hydrous manganese oxide formed in situ in the process of oxidation between $\mathrm{Mn}$ (II) and ozone, rather than by soluble Mn(II) itself. These studies have demonstrated that Mn catalytic ozonation has high potential applications in removing refractory compounds in water solution. However, the catalytic mechanism is unclear and need to be further explored.

In this paper, it was found that addition of $\mathrm{Mn}^{2+}$ promoted the ozonation of 2,4-dinitrotoluene (DNT) in the presence of oxalic acid. And, in situ formation $\mathrm{MnO}_{2}$ cannot promote the DNT degradation. A cycle $\mathrm{Mn}^{2+}$ catalytic mechanism was revealed. 2,4-DNT, one typical kind of dinitrotoluenes, is listed as Toxics Release Inventory chemicals because of its toxicity and possible carcinogenicity [8]. It is difficult to be degraded via conventional oxidation processes and single ozonation is also limited to destruct 2,4-DNT efficiently [9]. Thus, it is selected as the target compound in the present study. 


\section{Experimental}

\subsection{Materials}

2,4-Dinitrotoluene (99.9\%) was used as a model compound for catalytic ozonation. It was purchased from Beijing Chemical Co. (Beijing, China). A stock solution of $100 \mathrm{mg} / \mathrm{L}$ was prepared by dissolving DNT into deionized water, and was further diluted to $10 \mathrm{mg} / \mathrm{L}$ with deionized water before use. Ozone was produced from pure oxygen using the "corona discharge" method in a laboratory ozonator (Mitsubishi Ozonizer, OS-n, Japan). The manganese stock solution was prepared by dissolving $\mathrm{MnSO}_{4} \cdot \mathrm{H}_{2} \mathrm{O}$ in deionized water, which had a Mn concentration of $200 \mathrm{mg} / \mathrm{L}$. 5,5Dimethyl-1-pyrroline- $N$-oxide (DMPO) used to detect radicals in ESR experiment was from Aldrich. Methanol of HPLC grade was purchased from Fisher Company. Other reagents such as oxalic acid, sodium thiosulphate, potassium iodide, potassium indigo trisulfonate, etc., were used without further purification. All glassware was soaked in chromic acid, then rinsed with tap water and deionized water.

\subsection{Ozonation procedure}

The catalytic ozonation experiments were carried out in a $2.5 \mathrm{~L}$ glass reactor at room temperature $\left(25^{\circ} \mathrm{C}\right)$ in a semi-batch mode. The aqueous solution of substrates was placed into the reactor before starting the reaction. The $\mathrm{pH}$ was adjusted with sulfuric acid and sodium hydroxide. Then the reaction was initiated by bubbling the ozone/oxygen mixture. The solution was continuously stirred with a magnetic bar. Ozone gas was bubbled continuously into $1.0 \mathrm{~L}$ of reaction mixture through a porous glass membrane at the bottom of the reactor for $30 \mathrm{~min}$. Ozone gas-flow rate and concentration were controlled at $200 \mathrm{~mL} / \mathrm{min}$ and $5.6 \pm 0.2 \mathrm{mg} / \mathrm{L}$, respectively. The residual ozone in the off-gas was absorbed by KI solution. The samples were withdrawn from the outlet at regular intervals and the oxidation reaction was quenched by adding a small amount of sodium thiosulphate. Samples were stored at $4{ }^{\circ} \mathrm{C}$ and were analyzed within $24 \mathrm{~h}$.

\subsection{ESR procedure}

Electron spin resonance experiment was applied to determine hydroxyl radicals generated in ozonation process by using a nitron spin-trapping reagent DMPO. ESR spectra was recorded in the X-band on a Bruker electron spin resonance ESP 300E. ESR measurements were conducted at room temperature under the following conditions: modulation amplitude $2.0 \mathrm{G}$; microwave power of $10.00 \mathrm{~mW}$; modulation frequency $100 \mathrm{kHz}$; sweep width $100.0 \mathrm{G}$; receiver gain $1.00 \mathrm{E}+005$.

\subsection{Analysis}

Aqueous dissolved ozone concentration was determined colormetrically by using the indigo method [10]. The adsorption measurements were performed at $600 \mathrm{~nm}$ on a U-3010 UV-vis spectrophotometer (Hitachi, Japan). The ozone concentration in the gas phase was measured with iodometric method [11] before the ozone was introduced into the reactor. The concentration of total organic carbon (TOC) was analyzed using a multi N/C 3000 TOC analyzer (Analyti kjena AG, Germany) based on carbon dioxide infrared adsorption. The $\mathrm{pH}$ of solution was measured using Thermo Orion model 410 (Thermo Orion, USA). The meter was calibrated daily with NIST buffers of $\mathrm{pH} 4.01$ and 7.00. DNT concentration was analyzed by reversed-phase high performance liquid chromatogram (HPLC) with a Hitachi HPLC apparatus (Diode Array
Detector L-2450, Column Oven L-2300, and Pump L-2130). An Allsphere ODS-25 u column (Alltech, USA), $250 \mathrm{~mm} \times 46 \mathrm{~mm}$, was used and the column temperature was $40^{\circ} \mathrm{C}$. The mobile phase was a mixture of 60:40 methanol/water. The injection volume was $20 \mu \mathrm{L}$, the flow rate was $1.0 \mathrm{~mL} / \mathrm{min}$ and the wavelength of the UV absorbance detector was $250 \mathrm{~nm}$. Under these conditions, the retention time of DNT was $7.1 \mathrm{~min}$. Concentration of nitrate $\left(\mathrm{NO}_{3}{ }^{-}\right)$ in water was measured using an ion chromatogram (Metrohm 861 advanced compact IC) equipped with a conductivity detector and a 250/4.0 mm column (Metrosep A Supp 4, Metrohm). The eluent was $1.8 \mathrm{mM} \mathrm{Na}_{2} \mathrm{CO}_{3}$ and $1.7 \mathrm{mM} \mathrm{NaHCO}$ solution. Dissolved manganese concentration in solution was determined by ICP/AES (inductively coupled plasma atomic emission spectroscopy) method (SCIEX PerkinElmer Elan mode 5000). Samples for GC-MS analysis were prepared by the following procedure. The samples were filtered to remove particles through $0.45 \mu \mathrm{m}$ filter. The solution was evaporated by freeze-dried method. The residue was dissolved in $5 \mathrm{~mL}$ methylene chloride, and derivatized with $0.1 \mathrm{~mL}$ BSTFA/TMCS for $30 \mathrm{~min}$ at $60^{\circ} \mathrm{C}$. Then the sample was dried with $\mathrm{Na}_{2} \mathrm{SO}_{4}$ and concentrated to $1 \mathrm{~mL}$ to be analyzed. GC-MS analysis was carried out on an Agilent 7890GC/5975MSD with a HP-5 MS capillary column. The column was used with the following temperature procedure: $80^{\circ} \mathrm{C}$ hold for $6 \mathrm{~min}$, ramp at $4{ }^{\circ} \mathrm{C} / \mathrm{min}$ to $200^{\circ} \mathrm{C}$, and $200^{\circ} \mathrm{C}$ hold for $20 \mathrm{~min}$. The injector port was at $280^{\circ} \mathrm{C}$, and the carrier gas was helium.

\section{Results and discussion}

\subsection{Degradation of DNT}

Firstly, degradation of DNT was compared in several ozonation systems. As shown in Fig. 1, 35\% DNT was degraded by ozonation alone in $15 \mathrm{~min}$, the addition of $\mathrm{Mn}^{2+}$ or oxalic acid alone did not promote the degradation of DNT. And, the addition of $2 \mathrm{mg} / \mathrm{L} \mathrm{Mn}^{2+}$ had negative effect on DNT conversion. However, 65\% DNT was degraded in $15 \mathrm{~min}$ by ozonation with the simultaneous addition of $0.2 \mathrm{mg} / \mathrm{L} \mathrm{Mn}^{2+}$ and $4 \mathrm{mg} / \mathrm{L}$ oxalic acid. It is clear that only when $0.2 \mathrm{mg} / \mathrm{L} \mathrm{Mn}^{2+}$ and $4 \mathrm{mg} / \mathrm{L}$ oxalic acid coexisted in ozonation system, DNT degradation was significantly promoted.

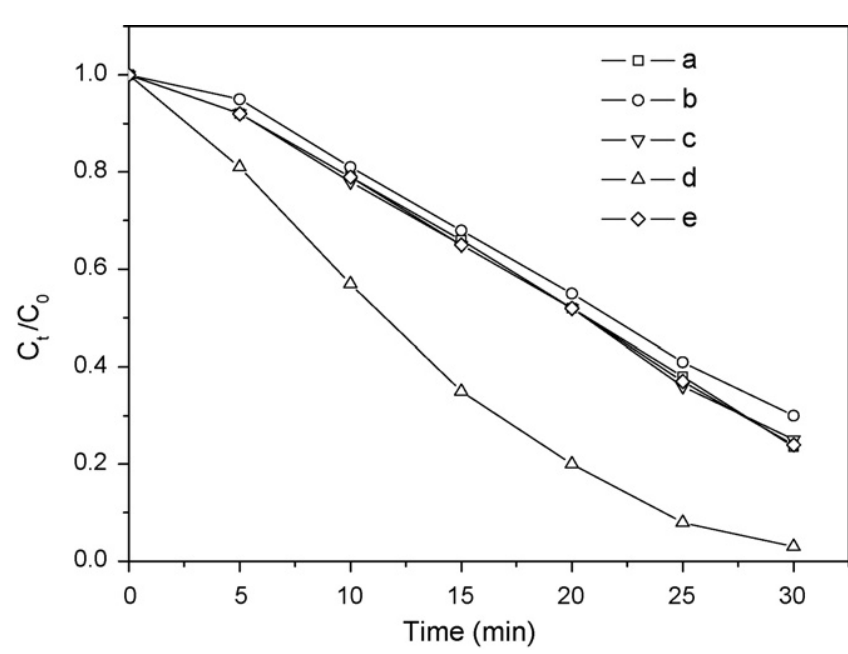

Fig. 1. DNT degradation in several ozonation systems: (a) ozonation alone; (b) ozonation coupled with $2 \mathrm{mg} / \mathrm{L} \mathrm{Mn}^{2+}$; (c) ozonation coupled with $0.2 \mathrm{mg} / \mathrm{L} \mathrm{Mn}^{2+}$; (d) ozonation catalyzed by $0.2 \mathrm{mg} / \mathrm{L} \mathrm{Mn}^{2+}$ in presence of $4 \mathrm{mg} / \mathrm{L}$ oxalic acid; (e) ozonation coupled with $4 \mathrm{mg} / \mathrm{L}$ oxalic acid. Conditions: $T=25^{\circ} \mathrm{C}$, initial pH 5.5, initial DNT concentration $=10 \mathrm{mg} / \mathrm{L}$, ozone gas concentration $=5.6 \mathrm{mg} / \mathrm{L}$, and ozone mixture gas flow $=200 \mathrm{~mL} / \mathrm{min}$. 
As an electrophilic agent, ozone easily reacts with aromatic compounds that have electron donor groups (e.g., $\mathrm{OH}$ and $\mathrm{NH}_{2}$ ). These compounds have high electron densities on aromatic ring [12]. The substitution of two strong electron-withdrawing nitro groups decrease the electron density on aromatic ring of DNT, thus reduce its reactivity with ozone. But, $\mathrm{Mn}^{2+}$ is easy to be oxidized by ozone [13]. Thus, in ozonation system where $\mathrm{Mn}^{2+}$ and DNT coexisted $\mathrm{Mn}^{2+}$ would be oxidized into $\mathrm{MnO}_{2}$ preferentially. The color of the solution changed gradually from the initial colorless to brown after introduction of ozone into the solution, and the color remained brown in the subsequent reaction process. Because oxidation of $\mathrm{Mn}^{2+}$ consumed a certain amount of ozone, the addition of $2 \mathrm{mg} / \mathrm{L}$ $\mathrm{Mn}^{2+}$ had negative effect on DNT conversion compared to ozonation alone. This phenomenon also demonstrated that manganese dioxide formed in situ had no promotion on DNT conversion. However, in ozonation with simultaneous addition of oxalic acid and $\mathrm{Mn}^{2+}$, the brown color was never observed in the reaction time. The process in which oxalic acid and $\mathrm{Mn}^{2+}$ coexisted was called catalytic ozonation in the following text.

Furthermore, TOC removal was examined in ozonation alone and catalytic ozonation. As shown in Fig. 2, TOC removal in catalytic ozonation was more than $40 \%$ after 30 min treatment, but it was less than $20 \%$ in ozonation alone. Thus, $\mathrm{Mn}^{2+}$ catalystic ozonation not only increased the degradation rate of DNT but also increased its mineralization degree.

\subsection{Evolution of dissolved ozone concentration}

It can be seen from Fig. 3 that dissolved ozone gradually accumulated in the whole single ozonation process, and its concentration reached about $1.2 \mathrm{mg} / \mathrm{L}$ at $30 \mathrm{~min}$. But during the course of catalytic ozonation, dissolved ozone concentration remained low level in $30 \mathrm{~min}$, and the maximum value was less than $0.5 \mathrm{mg} / \mathrm{L}$. This result suggested that the presence of $\mathrm{Mn}^{2+}$ and oxalic acid did enhance dissolved ozone decomposition rate and led to the low concentration of dissolved ozone.

In order to further demonstrate that the addition of $\mathrm{Mn}^{2+}$ and oxalic acid accelerated decomposition of dissolved ozone, the static kinetics of ozone decomposition was investigated. DNT solution with $\mathrm{Mn}^{2+}$ or without $\mathrm{Mn}^{2+}$ was added into the water saturated with ozone, and the samples were withdrawn to determine the concentration of dissolved ozone. The plot of $\operatorname{Ln}\left(C_{t} / C_{0}\right)$ versus time

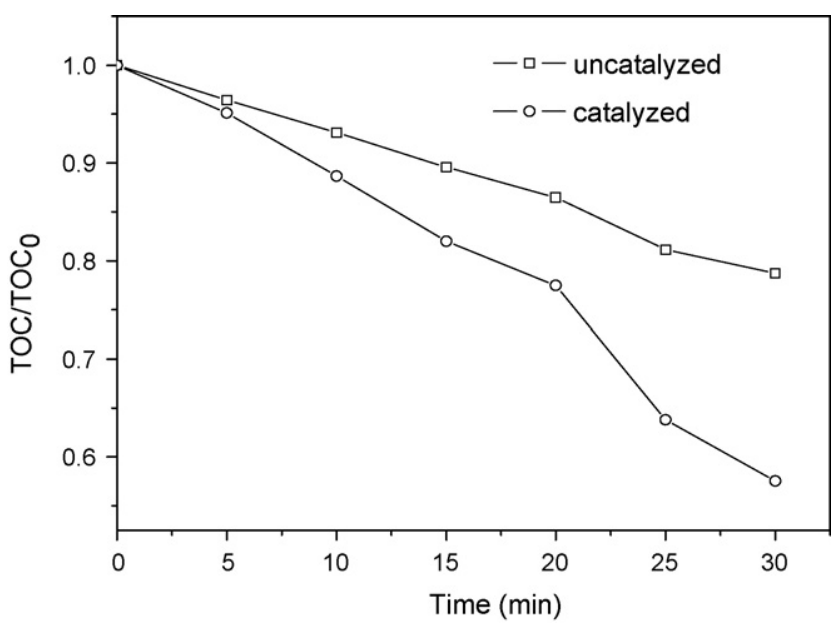

Fig. 2. TOC removal during uncatalyzed and catalyzed ozonation. Conditions: $T=25^{\circ} \mathrm{C}$, initial $\mathrm{pH} 5.5$, initial DNT concentration $=10 \mathrm{mg} / \mathrm{L}, \mathrm{Mn}^{2+}$ concentration $=0.2 \mathrm{mg} / \mathrm{L}$, oxalic acid concentration $=4 \mathrm{mg} / \mathrm{L}$, ozone gas concentration $=5.6 \mathrm{mg} / \mathrm{L}$, and ozone mixture gas flow $=200 \mathrm{~mL} / \mathrm{min}$.

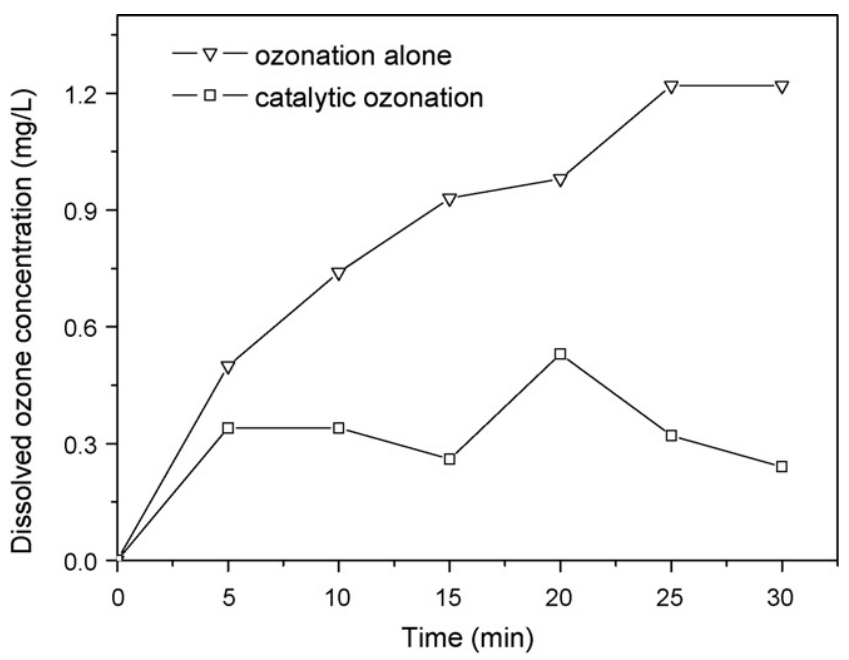

Fig. 3. Evolution of dissolved ozone concentration with time corresponding to ozonation alone and catalytic ozonation. Conditions: $T=25^{\circ} \mathrm{C}$, initial $\mathrm{pH} 5.5$, initial DNT concentration $=10 \mathrm{mg} / \mathrm{L}, \mathrm{Mn}^{2+}$ concentration $=0.2 \mathrm{mg} / \mathrm{L}$, oxalic acid concentration $=4 \mathrm{mg} / \mathrm{L}$, ozone gas concentration $=5.6 \mathrm{mg} / \mathrm{L}$, ozone mixture gas flow $=200 \mathrm{~mL} / \mathrm{min}$.

is shown in Fig. 4. Linear relationship was fitted to the curve and two equations can be determined:

$\operatorname{Ln}\left(C_{t} / C_{0}\right)=-0.0055 t, \quad r^{2}=0.8963 \leq$

$\operatorname{Ln}\left(C_{t} / C_{0}\right)=-0.0357 t, \quad r^{2}=0.9709$

$C_{t}$ is the concentration of dissolved ozone corresponding to different time, and $C_{0}$ is the initial concentration of dissolved ozone, $t$ is the time. Eqs. (1) and (2) depicts ozone decomposition kinetics in ozonation alone and catalytic ozonation, and the high values of $r^{2}$ indicated that ozone decomposition followed first-order kinetics. The rate constant in ozonation alone is $0.0055 \mathrm{~s}^{-1}$, which is far less than $0.0357 \mathrm{~s}^{-1}$ in catalytic ozonation. This result demonstrated that the addition of $\mathrm{Mn}^{2+}$ and oxalic acid led to the increase of ozone decomposition rate in catalytic ozonation.

\subsection{Effect of carbonate on catalytic ozonation}

It is well known that carbonate is radical scavenger [14], which has a strong quenching effect on hydroxyl radical reaction

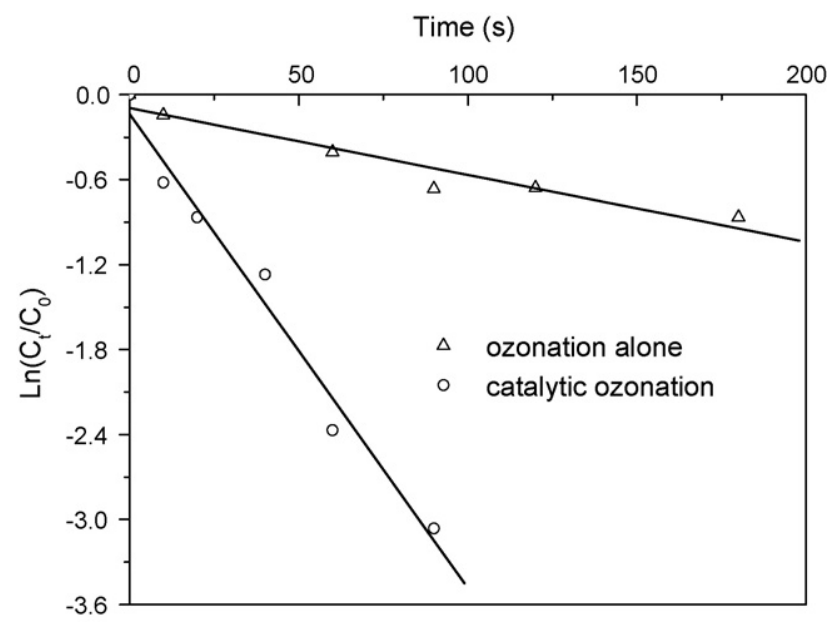

Fig. 4. Kinetics of ozone decomposition in ozonation alone and catalytic ozonation. Conditions: DNT concentration $=10 \mathrm{mg} / \mathrm{L}, \mathrm{Mn}^{2+}$ concentration $=0.2 \mathrm{mg} / \mathrm{L}$, and initial dissolved ozone concentration $=2.3 \mathrm{mg} / \mathrm{L}$. 


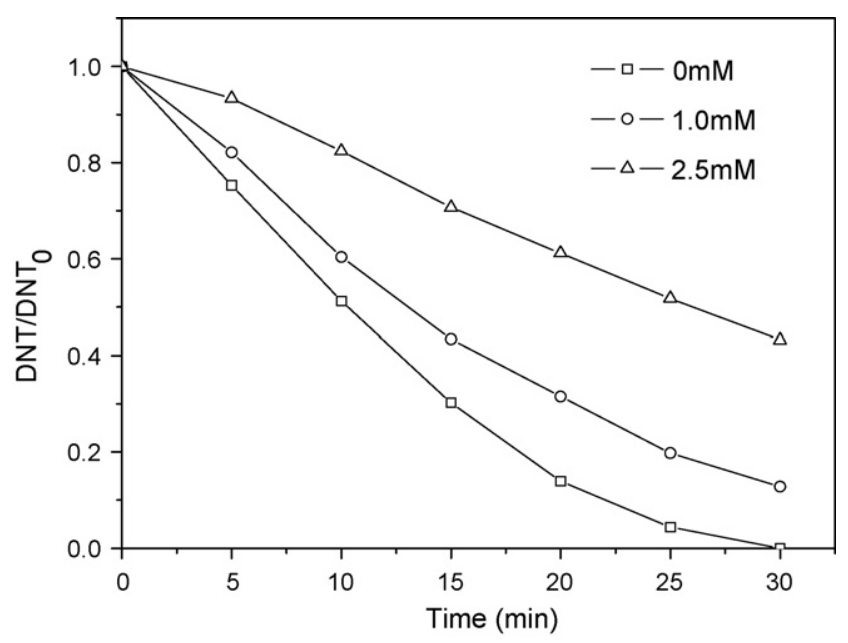

Fig. 5. Effect of carbonate concentration on DNT degradation in catalytic ozonation. Conditions: $T=25^{\circ} \mathrm{C}$, initial DNT concentration $=10 \mathrm{mg} / \mathrm{L}, \mathrm{Mn}^{2+}$ concentration $=0.2 \mathrm{mg} / \mathrm{L}$, oxalic acid concentration $=4 \mathrm{mg} / \mathrm{L}$, ozone gas concentration $=5.8 \mathrm{mg} / \mathrm{L}$, and ozone mixture gas flow $=200 \mathrm{~mL} / \mathrm{min}$.

$\left(\mathrm{KCO}_{3}{ }^{2-}=3.9 \times 10^{8} \mathrm{M}^{-1} \mathrm{~s}^{-1}\right)$ [15]. Thus, the effect of carbonate on the degradation of DNT was tested in order to identify the role of hydroxyl radicals in $\mathrm{Mn}^{\mathrm{II}}$-catalytic ozonation in the presence of oxalic acid. It can be seen from Fig. 5 that the addition of $1.0 \mathrm{mM}$ carbonate obviously reduced the degradation rate of DNT. And, at the carbonate concentration of $2.5 \mathrm{mM}$, DNT conversion was largely inhibited and only 50\% DNT was degraded within $30 \mathrm{~min}$. These results confirmed that hydroxyl radicals played an important role in degradation of DNT by $\mathrm{Mn}^{\mathrm{II}}$-catalytic ozonation.

\subsection{ESR analysis}

ESR spectroscopy/spin-trapping technique is widely utilized in radical analysis because of its sensitivity and selectivity. Hydroxyl radical is very unstable in aqueous solution, but it can be trapped by DMPO into formation of stable adduct, which can be measured qualitatively and quantitatively by ESR. In the presence and absence of $\mathrm{Mn}^{2+}$ and oxalic acid, ozone solution was mixed with DMPO solution. After $2 \mathrm{~min}$, it was analyzed by ESR immediately. As shown in Fig. 6(a), the spectrum was composed of quartet lines having peak height ratio of $1: 2: 2: 1$. The ESR parameters coincided with those of typical DMPO-OH adduct [16], and the result confirmed that the quartet signal is DMPO-OH adduct.

The signal strength of DMPO-OH adduct represents the amount of hydroxyl radicals during ozonation to some extent. Oxalic acid or $\mathrm{Mn}^{2+}$ or both of them was added into $30 \mu \mathrm{L}$ aqueous solution containing DMPO, and then $100 \mu \mathrm{L}$ ozone-saturated aqueous solution was added immediately. Two minutes after vigorous agitation of the mixture, the signal was started to be collected using $25 \mu \mathrm{L}$ of the sample solution. The value of signal strength of DMPO-OH adduct was equal to the sum of peak absolute value and valley absolute value. Fig. 6(b) illustrates the signal strength of DMPO$\mathrm{OH}$ adducts in several different ozonation systems. As shown in Fig. 6(b), there was no significant difference of signal strength of hydroxyl radical produced among ozonation, ozonation coupled with $\mathrm{Mn}^{2+}$, and ozonation coupled with oxalic acid. However, its strength largely increased in ozonation catalyzed by $\mathrm{Mn}^{2+}$ in the presence of oxalic acid. In ozone-Mn binary system absence of oxalic acid, $\mathrm{Mn}^{2+}$ was quickly oxidized into higher valent manganese oxide. But in ozone-Mn-oxalic acid ternary system, owing to presence of oxalic acid, Mn existed as the form of $\mathrm{Mn}^{2+}$. Combina-
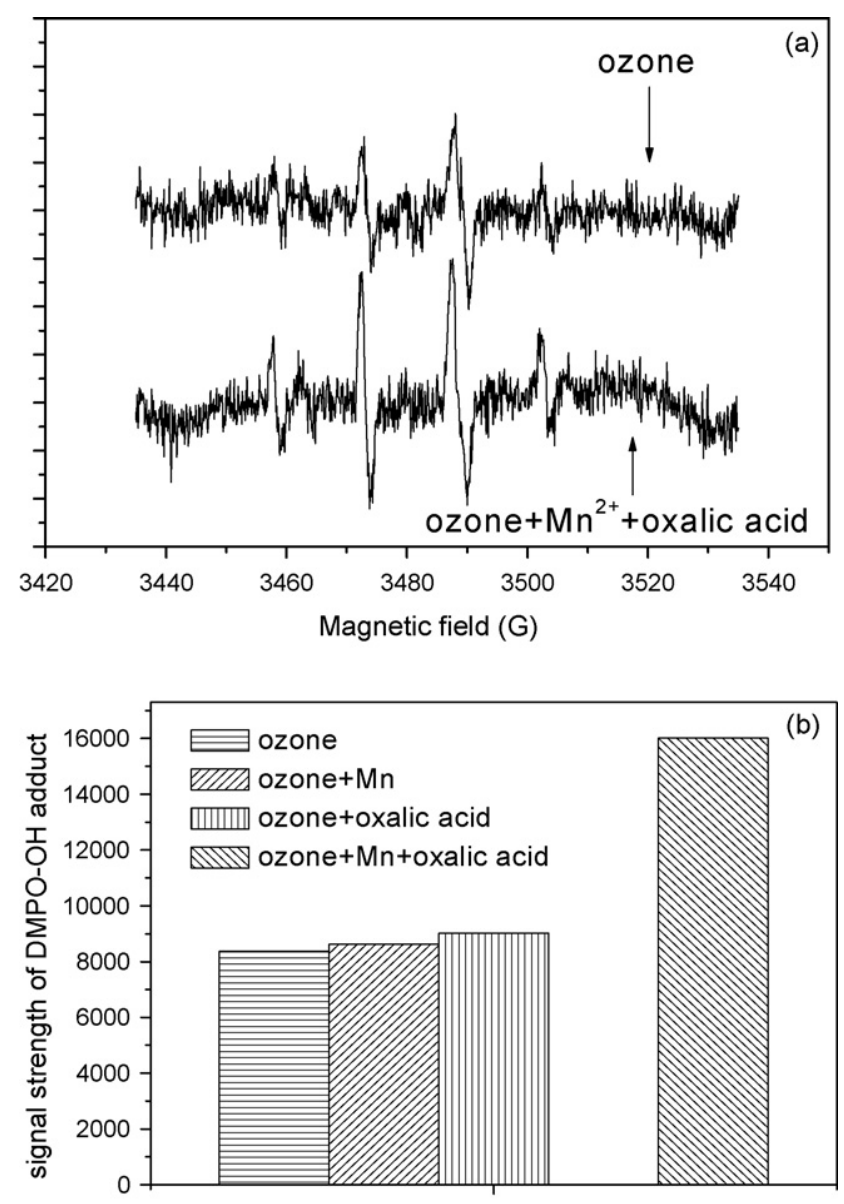

Fig. 6. ESR spectrum corresponding to blank and catalytic ozonation (a) and signal strength of DMPO-OH adduct during several systems (b). Conditions: $\mathrm{Mn}^{2+}$ concentration $=0.2 \mathrm{mg} / \mathrm{L}$, oxalic acid concentration $=4 \mathrm{mg} / \mathrm{L}$, DMPO concentration $=0.1 \mathrm{mM}$.

tion with the DNT degradation results in several ozonation systems, it can be concluded that the presence of $\mathrm{Mn}^{2+}$ in the whole reaction time was important for continuous generation of large amount of hydroxyl radicals.

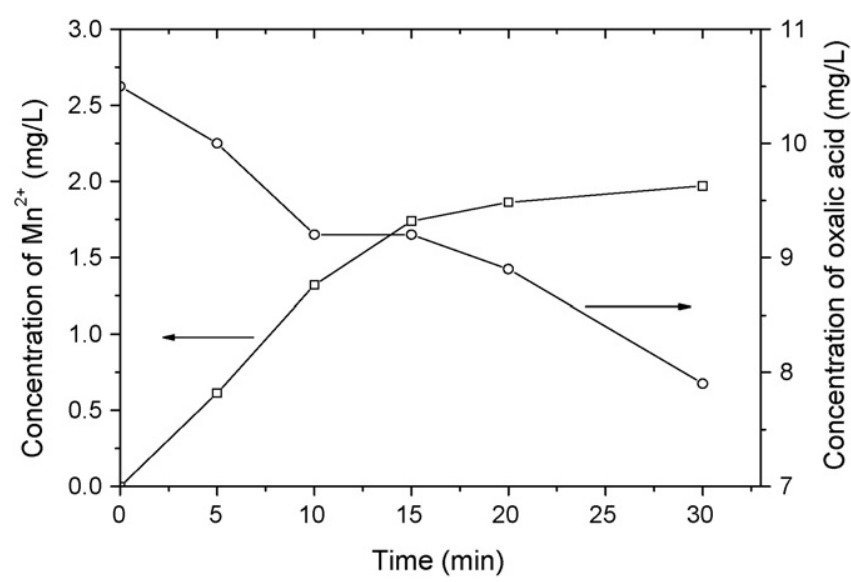

Fig. 7. Evolution of dissolved manganese concentration and oxalic acid concentration during reaction between oxalic acid and manganese oxide. Conditions: initial concentration of oxalic acid $=10.5 \mathrm{mg} / \mathrm{L}$. 


\subsection{Proposed $\mathrm{Mn}^{2+}$ catalytic mechanism}

As previously assumed, Mn must be exist as a form of ion status to have a sustainable production of hydroxyl radicals in solution. In ozone-Mn-DNT-oxalic acid system the possible way to implement it is reduction of manganese oxide by oxalic acid, so reaction of oxalic acid and manganese oxide was investigated. As shown in
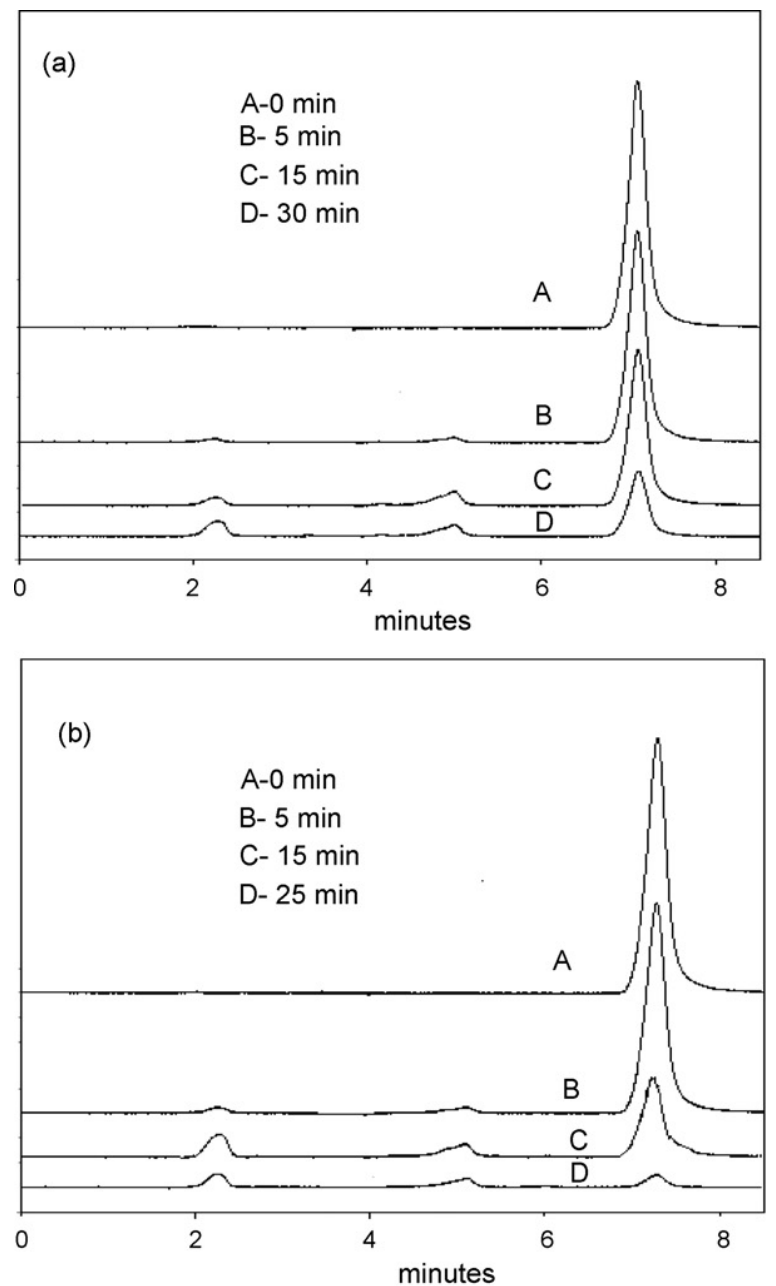

(c)

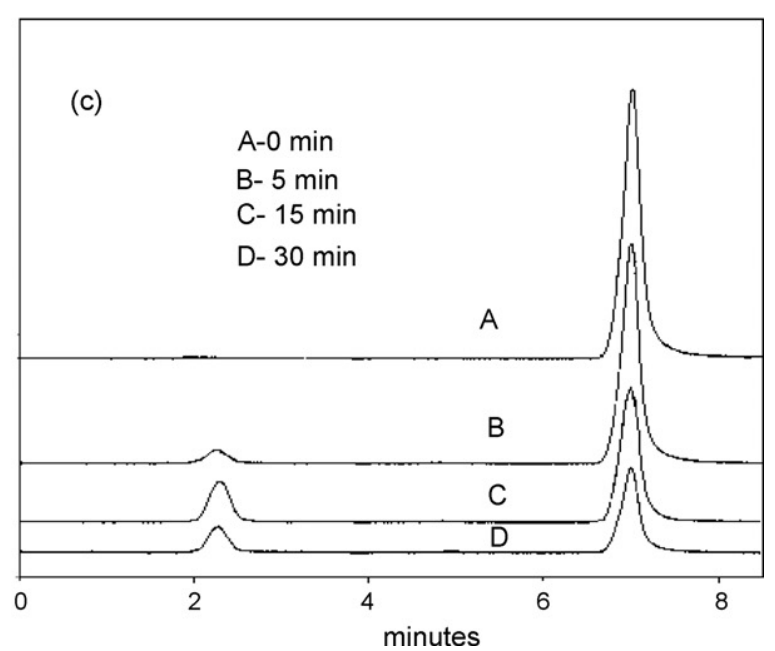

Fig. 8. HPLC spectrums corresponding to different time during several ozonation systems: (a) ozonation alone; (b) catalytic ozonation; (c) catalytic ozonation with addition of $1.0 \mathrm{mM}$ carbonate).
Fig. 7, with the extension of the reaction time, the concentration of oxalic acid gradually decreased and correspondingly the concentration of dissolved manganese ion increased. It is stated that oxalic acid can also have the ability to reduce manganese dioxide to $\mathrm{Mn}^{2+}$. A similar conclusion was drawn from the published work [17].

Based on the above experimental results, the following catalytic mechanism was proposed: In ozone-Mn-DNT-oxalic acid system, $\mathrm{Mn}^{2+}$ catalyzed decomposition of ozone to generate hydroxyl radicals and at the same time $\mathrm{Mn}^{2+}$ was oxidized to form higher valent manganese oxide. DNT was degraded by reaction with hydroxyl radicals, and oxalic acid reduced manganese oxide into lower valent $\mathrm{Mn}^{2+}$. Thus, a catalytic cycle was completed.

$$
\begin{aligned}
& \mathrm{Mn}^{2+}+\mathrm{O}_{3}+\mathrm{H}^{+} \rightarrow \mathrm{Mn}^{3+}+\cdot \mathrm{OH}+\mathrm{O}_{2} \\
& 2 \mathrm{Mn}^{3+}+2 \mathrm{H}_{2} \mathrm{O} \rightarrow \mathrm{Mn}^{2+}+\mathrm{MnO}_{2}+4 \mathrm{H}^{+} \\
& \cdot \mathrm{OH}+\mathrm{DNT} \rightarrow \text { intermediates } \\
& \mathrm{MnO}_{2}+\mathrm{H}_{2} \mathrm{C}_{2} \mathrm{O}_{4}+2 \mathrm{H}^{+} \rightarrow \mathrm{Mn}^{2+}+2 \mathrm{CO}_{2}+2 \mathrm{H}_{2} \mathrm{O} \\
& \mathrm{Mn}^{2+}+\mathrm{O}_{3}+\mathrm{H}^{+} \rightarrow \mathrm{Mn}^{3+}+\cdot \mathrm{OH}+\mathrm{O}_{2}
\end{aligned}
$$
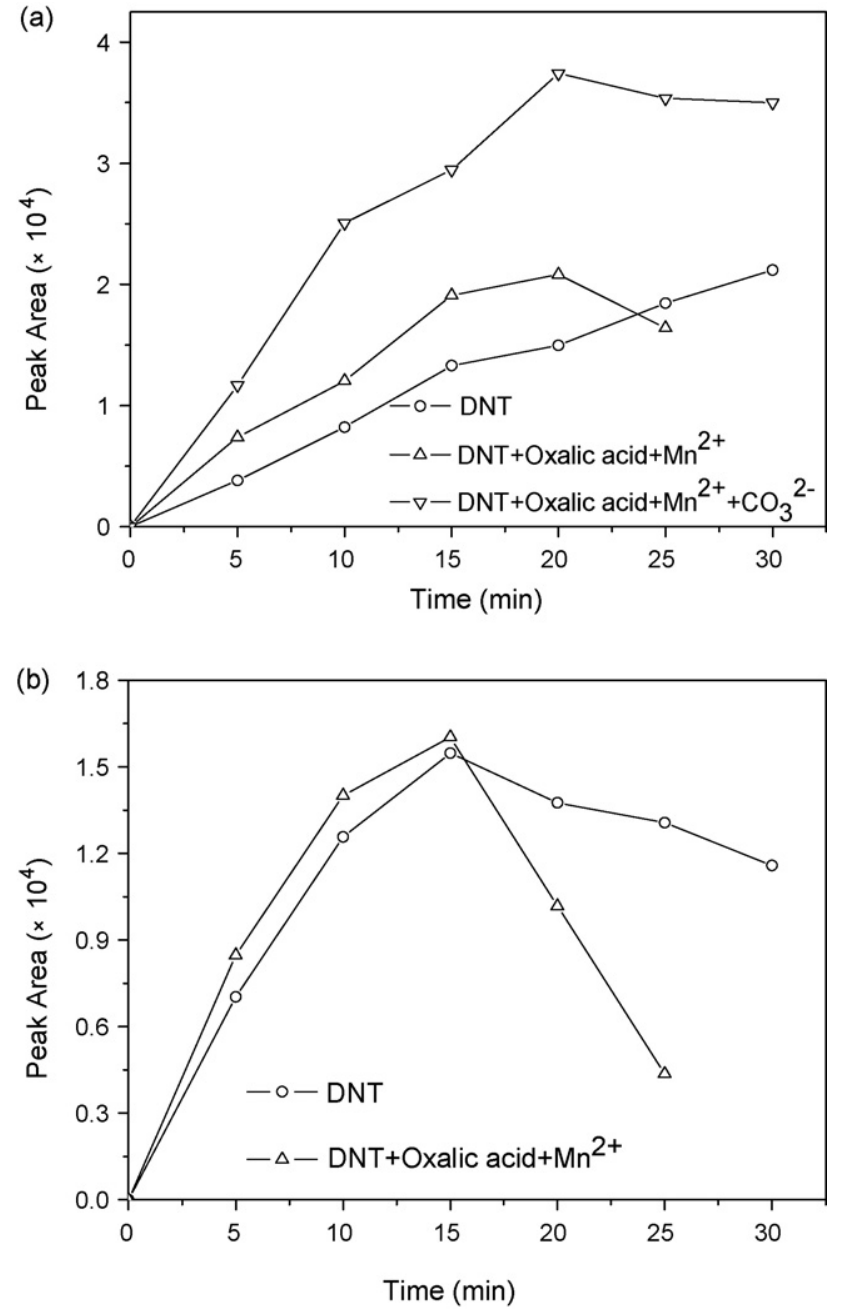

Fig. 9. Evolution of product $(\mathrm{RT}=2.2 \mathrm{~min})$ during several ozonation systems (a) and evolution of product ( $\mathrm{RT}=5.0 \mathrm{~min}$ ) during several ozonation systems (b). Conditions: $T=25^{\circ} \mathrm{C}$, initial DNT concentration $=10 \mathrm{mg} / \mathrm{L}, \mathrm{Mn}^{2+}$ concentration $=0.2 \mathrm{mg} / \mathrm{L}$, oxalic acid concentration $=4 \mathrm{mg} / \mathrm{L}$, ozone gas concentration $=5.6 \mathrm{mg} / \mathrm{L}$, and ozone mixture gas flow $=200 \mathrm{~mL} / \mathrm{min}$. 


\subsection{Intermediates analysis}

\subsubsection{HPLC analysis}

Fig. 8 depicts the results of DNT degradation and production of organic intermediates by HPLC during several ozonation systems. As seen from Fig. 8, after reaction the height of DNT peak ( $\mathrm{RT}=7.1 \mathrm{~min}$ ) decreased by different levels, it was lowest after 30 min reaction in catalytic ozonation. What's more, two intermediates were produced with the degradation of DNT, one's RT is $2.2 \mathrm{~min}$, and the other's is $5.0 \mathrm{~min}$. It was interesting that there was no production of intermediate (its RT is $5.0 \mathrm{~min}$ ) during the catalytic ozonation with the addition of $1.0 \mathrm{mM}$ carbonate. The addition of carbonate quenched the hydroxyl radicals produced by catalytic process, so it was concluded that the intermediate product ( RT $=5.0 \mathrm{~min}$ ) was formed by reaction of DNT and hydroxyl radical. And, the addition of carbonate did not inhibit the production of the intermediate $(\mathrm{RT}=2.2 \mathrm{~min})$, so it can be produced by direct reaction of DNT and ozone.

Fig. 9 showed the quantities of the two intermediate products and the peak area was used to estimate them semi-quantitatively. As shown in Fig. 9(a), the peak area of the intermediate product ( $\mathrm{RT}=2.2 \mathrm{~min}$ ) gradually increased in the ozonation process, but in catalytic ozonation process it increased to a maximum at the earlier stage of reaction and decreased slowly at the later stage, which demonstrated that the intermediate product $(\mathrm{RT}=2.2 \mathrm{~min}$ ) was gradually degraded by ozone or hydroxyl radical. The interme-

Table 1

Main products of the catalytic ozonation of DNT detected by GC-MS

Retention time (min)

Oxalic acid
Molecular structure<smiles>C=C(O)C(=O)O</smiles><smiles>O=C(O)c1ccccc1</smiles><smiles>O=C(O)CCC(=O)O</smiles><smiles>O=C(O)C(O)C(=O)O</smiles><smiles>O=C(O)/C(O)=C/O</smiles><smiles>O=Cc1ccc([N+](=O)[O-])cc1[N+](=O)[O-]</smiles> 


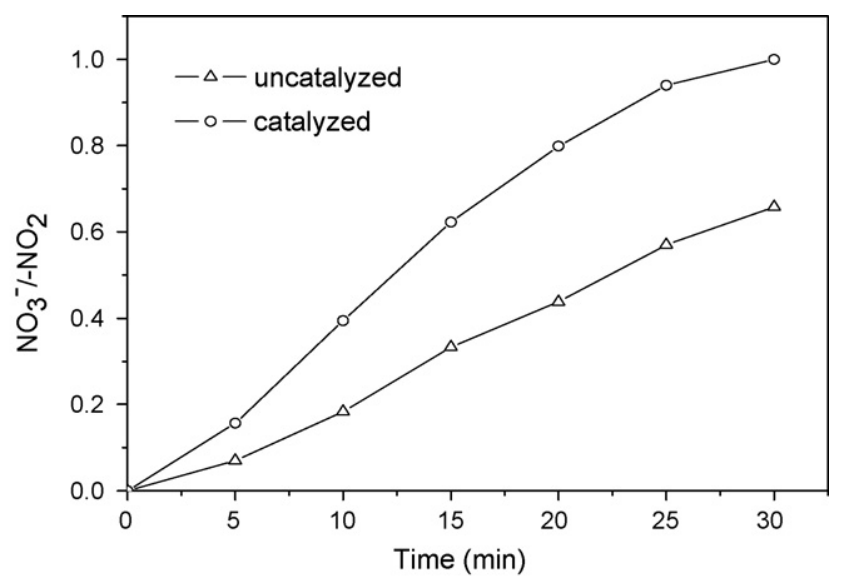

Fig. 10. Evolution of nitrate concentration in ozonation alone and catalytic ozonation. Conditions: $T=25^{\circ} \mathrm{C}$, initial DNT concentration $=10 \mathrm{mg} / \mathrm{L}, \mathrm{Mn}^{2+}$ concentration $=0.2 \mathrm{mg} / \mathrm{L}$, initial oxalic acid concentration $=4 \mathrm{mg} / \mathrm{L}$, ozone gas concentration $=5.8 \mathrm{mg} / \mathrm{L}$, and ozone mixture gas flow $=200 \mathrm{~mL} / \mathrm{min}$.

diate product $(\mathrm{RT}=5.0 \mathrm{~min})$ accumulated to a high level at $15 \mathrm{~min}$ of reaction and then was destroyed by different rates in single and catalytic ozonation processes.

\subsubsection{Identification of intermediates by GC-MS}

Typical samples were selected and analyzed by GC-MS in the catalytic ozonation. The major intermediate products detected are listed in Table 1. All the identified compounds were unequivocally identified using the NIST05 library database with fit values higher than $90 \%$. The main intermediate products included 2,4dinitrobenzaldehyde, the aromatic acids such as benzoic acid, and the aliphatic acids such as 2-hydroxyl-propanedioic acid, butanedioic acid, 2-hydroxyl-propanoic acid. Identification of 2,4dinitrobenzaldehyde indicated that the oxidation took place at the methyl group, followed by opening of the phenyl ring to form small molecular organic acids. The aliphatic acids were further oxidized into carbon dioxide and water.

\subsubsection{Production of nitrate}

The evolution of nitrate ion in ozonation alone and catalytic ozonation is showed in Fig. 10. An intensive formation of nitrate took place from the very beginning of the process in two cases. As can be seen from Fig. 10, catalytic ozonation led to $100 \%$ nitrate ion production after $30 \mathrm{~min}$ of treatment, that is to say both nitro groups of DNT molecule were oxidized into nitrate. By contrast, ozonation alone only allows for $64 \%$ production of nitrate.

\section{Conclusions}

This work studied manganese catalytic ozonation of 2,4dinitrotoluene (DNT) in the presence of oxalic acid. The addition of $\mathrm{Mn}^{2+}$ and oxalic acid significantly promoted DNT degradation and TOC removal. DNT degradation was inhibited in catalytic ozonation by the addition of carbonate. The simultaneous addition of $\mathrm{Mn}^{2+}$ and oxalic acid promoted decomposition of ozone in catalytic ozonation of DNT, so dissolved ozone concentration kept low level in the reaction. ESR experiments confirmed that larger amount of $\bullet \mathrm{OH}$ radicals generated in catalytic ozonation than that in ozonation alone. According to above results, a new cycle catalytic mechanism of manganese was proposed. Some organic intermediates were detected by HPLC and GC-MS in ozonation of DNT. The production of nitrate ion in catalytic ozonation was more than that in single ozonation.

\section{Acknowledgments}

This work was supported by the Funds for Creative Research Groups of China (Grant No. 50621804) and by National Natural Science Foundation of China (Grant No. 50538090).

\section{References}

[1] K. Barbara, Z. Maria, N. Jacek, Appl. Catal. B: Environ. 46 (2003) 639-669.

[2] J.B. Fernando, J.R. Francisco, M. Ramon, Ind. Eng. Chem. Res. 42 (2003) 3210-3217.

[3] S. Cortés, J. Sarasa, P. Ormad, R. Gracia, J.L. Ovelleiro, Ozone Sci. Eng. 22 (2000) 415-426.

[4] J.H. Qu, H.Y. Li, H.J. Liu, H. He, Catal. Today 90 (2004) 291-296.

[5] R. Andreozzi, V. Caprio, A. Insola, Water Res. 32 (1998) 1492-1496.

[6] J. Ma, M.H. Sui, T. Zhang, C.Y. Guan, Water Res. 39 (2005) 779-786.

[7] J. Ma, N.J.D. Graham, Water Res. 33 (1999) 785-793.

[8] D.L. Kaplan, A.M. Kaplan, Environ. Sci. Technol. 16 (1982) 566-571.

[9] J.B. Fernando, M.E. Jose, A.A. Miguel, Ind. Eng. Chem. Res. 37 (1998) 25-31.

[10] H. Bader, J. Hoigne, Water Res. 15 (1981) 449-456.

[11] M.C. Rand, A.E. Greenberg, M.J. Taras, Standard methods for the examination of water and wastewater, Washington, DC, 1992.

[12] S.P. David, Ph.D. Dissertation, University of Massachusetts, Amherst (2000).

[13] V.G. Urs, Water Res. 37 (2003) 1443-1467.

[14] J. Hoigne, H. Bader, Water Res. 19 (1985) 993-1004.

[15] J.L. Acero, G. Von, In Proceedings of Ozonation and AOPs in Water Treatment: Applications and Research, Poitiers, France, 1998.

[16] H. Utsumi, M. Hakoda, S. Shimbara, H. Nagaoka, Y. Chung, A. Hamada, Water Sci. Technol. 30 (1994) 91-99.

[17] F.P. Joaquin, A. Conchita, A. Elisenda, J. Colloid Interf. Sci. 177 (1996) 288-297. 